\title{
Taurine activates GABAergic networks in the neocortex of immature mice
}

\author{
Bogdan A. Sava ${ }^{\dagger}$, Rongqing Chen ${ }^{\dagger}$, Haiyan Sun, Heiko J. Luhmann and Werner Kilb* \\ Institute of Physiology, University Medical Center Mainz, Mainz, Germany
}

\section{Edited by:}

Laura Cancedda, Istituto Italiano di Tecnologia, Italy

Reviewed by:

Ivan Pavlov, University College

London, UK

Simo S. Oja, University of Tampere,

Finland

\section{*Correspondence:}

Werner Kill, Institute of Physiology,

University Medical Center Mainz,

Duesbergweg 6, 55128 Mainz,

Germany

e-mail:wkilb@uni-mainz.de

${ }^{+}$These authors have equally

contributed to the work and share first authorship.

\begin{abstract}
Although it has been suggested that taurine is the main endogenous neurotransmitter acting on glycine receptors, the implications of glycine receptor-mediated taurine actions on immature neocortical networks have not been addressed yet. To investigate the influence of taurine on the excitability of neuronal networks in the immature neocortex, we performed whole-cell patch-clamp recordings from visually identified pyramidal neurons and interneurons in coronal slices from C57BI/6 and GAD67-green fluorescent protein (GFP) transgenic mice (postnatal days $2-4$ ). In $46 \%$ of the pyramidal neurons bath-application of taurine at concentrations $\geq 300 \mu \mathrm{M}$ significantly enhanced the frequency of postsynaptic currents (PSCs) by $744.3 \pm 93.8 \%$ ( $n=120$ cells). This taurine-induced increase of PSC frequency was abolished by $0.2 \mu \mathrm{M}$ tetrodotoxin (TTX), $1 \mu \mathrm{M}$ strychnine or $3 \mu \mathrm{M}$ gabazine, but was unaffected by the glutamatergic antagonists 6-cyano-7-nitroquinoxaline-2,3-dione (CNOX) and ( \pm ) R(-)-3-(2-carboxypiperazine-4-yl)propyl-1-phosphonic acid (CPP), suggesting that taurine specifically activates GABAergic network activity projecting to pyramidal neurons. Cell-attached recordings revealed that taurine enhanced the frequency of action potentials (APS) in pyramidal neurons, indicating an excitatory action of the GABAergic PSCs. In order to identify the presynaptic targets of taurine we demonstrate that bath application of taurine induced in GAD67-GFP labeled interneurons an inward current that is mainly mediated by glycine receptors and can generate APs in these cells. We conclude from these results that taurine can enhance network excitability in the immature neocortex by selectively activating GABAergic interneurons via interactions with glycine receptors.
\end{abstract}

Keywords: $\mathrm{GABA}_{\mathrm{A}}$ receptor, glycine receptor, development, neocortex, GABAergic excitation, interneuron, cortical plate, subplate

\section{INTRODUCTION}

A variety of studies reported that ionotropic receptors for $\gamma$ amino butyric acid (GABA) are functionally expressed during pre- and early post-natal development (e.g., Laurie et al., 1992; Fritschy et al., 1994; Van Eden et al., 1995) and that such GABA receptors mediate depolarizing responses in immature hippocampal (Ben-Ari et al., 1989; Rivera et al., 1999; Sipila et al., 2005) and neocortical neurons (Owens et al., 1996; Achilles et al., 2007; Ben-Ari et al., 2012). $\mathrm{GABA}_{\mathrm{A}}$ receptors are critically involved in several developmental steps (reviewed in Wang and Kriegstein, 2009), like regulating neuronal proliferation (LoTurco et al., 1995; Haydar et al., 2000), migration (Behar et al., 2000; Cuzon et al., 2006; Heck et al., 2007), neurite growth (Sernagor et al., 2010) and synaptic integration (Wang and Kriegstein, 2008). Most of these effects are mediated by tonic GABAergic activation of nonsynaptic receptors (reviewed in Kilb et al., 2013). In addition to these non-synaptic processes, GABAergic synaptic inputs had been demonstrated in various neuronal populations of the neocortex during pre- and early post-natal stages (Owens et al., 1999; Kilb and Luhmann, 2001; Hanganu et al., 2002; Radnikow et al., 2002; Rheims et al., 2008). It has been suggested that
GABAergic depolarizations provide the excitatory drive necessary for early network activity (Sipila et al., 2005; Ben-Ari, 2006, 2012), although in the neocortex early synchronous network oscillations are mainly independent of GABAergic signaling (Garaschuk et al., 2000; Allene et al., 2008). Such early network activity probably also plays an important role in the functional maturation of neocortical circuits (Ben-Ari, 2002; Spitzer, 2006; Hanganu-Opatz, 2010; Kilb et al., 2011).

On the other hand, no major anatomically disturbances of the perinatal neocortex and hippocampus were observed in the absence of GABA (Ji et al., 1999) or synaptic GABA release (Wojcik et al., 2006), suggesting that other intrinsic GABAergic agonists may act on $\mathrm{GABA}_{\mathrm{A}}$ receptors during early development. Taurine, a partial agonist of $\mathrm{GABA}_{\mathrm{A}}$ (Albrecht and Schousboe, 2005) and glycine receptors (Flint et al., 1998), is one possible candidate. Taurine can be released by a variety of stimuli in the adult nervous system (Saransaari and Oja, 1998; Oja and Saransaari, 2000). A non-vesicular release of taurine can be induced by electrical stimulation and in the presence of a hypoosmolar solution in the immature neocortex (Flint et al., 1998; Kilb et al., 2008). Taurine has been shown to be directly involved in 
the development of the central nervous system (CNS; Palackal et al., 1986; Sturman et al., 1994; Maar et al., 1995; Behar et al., 2001) and influences the shift from depolarizing to hyperpolarizing GABAergic responses (Inoue et al., 2012). In accordance with the depolarizing effect of GABA, taurine also depolarizes different neuronal populations of the immature neocortex via an activation of $\mathrm{GABA}_{\mathrm{A}}$ and glycine receptors (Ito and Cherubini, 1991; Flint et al., 1998; Kilb et al., 2002, 2008). However, the effect of such depolarizing taurine responses on the network activity in the immature neocortex has to our knowledge not been investigated yet.

To analyze the influence of taurine on network activity in the immature neocortex we investigated the effect of taurine application on the spontaneous postsynaptic currents (PSCs) recorded in pyramidal neurons of the mouse neocortex at postnatal days $(\mathrm{P}) 2-4$. These experiments revealed that taurine induced a massive increase in the frequency of GABAergic PSCs, which is suppressed by the glycinergic agonist strychnine and mediated an excitatory response in these cells. Recordings from genetically labeled GABAergic interneurons showed that taurine induced an inward current, mainly mediated by glycine receptors, and thereby generate action potentials (APs) in these cells. These findings suggest that in the early postnatal neocortex taurine can activate GABAergic networks via an interaction with glycine receptors on GABAergic interneurons and may thereby influence the maturation of neocortical network.

\section{MATERIALS AND METHODS PREPARATION OF THE CORTICAL SLICES}

Animal handling was performed in accordance with EU directive 86/609/EEC for the use of animals in research and approved by the local ethical committee (Landesuntersuchungsanstalt RLP, Koblenz, Germany). All efforts were made to minimize the number of animals and their suffering. For electrophysiological experiments coronal slices of the neocortex were prepared from pups of C57Bl/6 or GAD67-GFP transgenic mice (Tamamaki et al., 2003) at P2-P4. Mice were deeply anesthetized by enflurane (Abbot, Wiesbaden, Germany). After opening of the skull, the brain was quickly removed and placed in ice-cold artificial cerebrospinal fluid (ACSF; composition given below). Wholebrain $400 \mu \mathrm{M}$ thick coronal slices were cut on a vibratome (HR2, Sigmann Elektronik, Hüffenhardt, Germany) and cut along the midline to separate the two hemispheres. Only coronal slices that according to an atlas of the developing rat brain (Paxinos and Franklin, 2001) included the primary somatosensory cortex were transferred to an incubation-storage chamber. Slices were allowed to recover for at least $1 \mathrm{~h}$ before recording. For some experiments a reduced slice preparation was required. For that coronal slices with a thickness of $400 \mu \mathrm{M}$ were placed under a binocular and trimmed with a scalpel blade to a width of approximately $2-3 \mathrm{~mm}$. In some of these slices the subplate (SP) and white matter were identified by eye and the SP was removed with a scalpel blade.

\section{ELECTROPHYSIOLOGICAL SETUP}

The videomicroscopic setup consisted of an upright microscope (BW51WI, Olympus) with infrared differential interference contrast (IR-DIC) optics (Dodt and Zieglgänsberger, 1990), and a CCD-camera (C5405, Hamamatsu, Japan). The video image was contrast enhanced by a video processor (C 2400, Hamamatsu) and visualized on a video-monitor. For whole-cell and cell-attached patch-clamp experiments pipettes were made from borosilicate tubing $(2.0 \mathrm{~mm}$ outside diameter, $1.16 \mathrm{~mm}$ inside diameter; Science Products, Hofheim, Germany) using a vertical puller (PP-83, Narishige, Tokyo, Japan) and filled with pipette solution (see below). The patch pipettes were connected to the headstage of a discontinuous voltage-clamp/current-clamp amplifier (SEC05L, NPI, Tamm, Germany). Signals were amplified, low-pass filtered at $3 \mathrm{kHz}$, visualized on an oscilloscope (HM507, Hameg Instruments), digitized on-line by an AD/DAboard (ITC-18, Heka, Lamprecht, Germany), recorded and processed with the software WINTIDA 5.0 (Heka), and stored on a personal computer. The slices were transferred into a submerged recording chamber, mounted on the fixed stage of the microscope and were superfused with ACSF at a rate of $1-2 \mathrm{ml} / \mathrm{min}$. All experiments were performed at $30 \pm 1^{\circ} \mathrm{C}$ maintained by a peltier-element based temperature controller (Luigs \& Neumann, Ratingen, Germany).

\section{ELECTROPHYSIOLOGICAL PROCEDURES AND ANALYSIS}

Resting membrane potential (RMP) was measured directly after establishing whole-cell configuration. All potentials were corrected for a liquid junction potential of $9.1 \mathrm{mV}$. Input resistance and capacitance were determined from amplitude and rise kinetics of voltage deflections to $300 \mathrm{~ms}$ hyperpolarizing current pulses. AP amplitude was defined as voltage difference between firing threshold and peak depolarization and AP width was measured at half-maximal amplitude. PSCs were detected and analyzed in continuous voltage-clamp recordings lasting at least $180 \mathrm{~s}$ at a holding potential $\left(E_{h}\right)$ of $-69.1 \mathrm{mV}$ (except where noted), using the program MiniAnalysis 4.3.3 (Synaptosoft, Leonia, NJ, USA). Frequencies of APs and PSCs were determined during at least $3 \mathrm{~min}$ of the recording immediately before agonist application for control conditions, and during the complete period of agonist application for the agonist condition. Holding currents were determined during a $c a .1$ min interval directly before agonist application for control conditions and during a similar interval in the maximal phase of the agonist response. Cells were considered as responsive to agonists, if the frequency of PSCs in the presence of agonists (calculated from inter-event intervals) was $4 \mathrm{x}$ larger than the standard deviation of the frequency during the control interval. For taurine concentrations $\leq 100 \mu \mathrm{M}$ cells were only considered as non-responsive, if the cells showed a taurine-induced increase in PSC frequency at higher taurine doses. The reversal potential $\left(E_{\mathrm{Rev}}\right)$ was calculated from the Goldman equation using $\mathrm{Cl}^{-}$concentrations, estimated $\mathrm{HCO}_{3}^{-}$concentrations and a relative bicarbonate permeability of 0.2 (Bormann et al., 1987). Cell-attached experiments were performed either under current-clamp conditions at a holdingpotential of $-60 \mathrm{mV}$ or under bridge-mode condition with no holding-current applied. Cells were considered as responsive to taurine application if AP frequency increases by more than $50 \%$ and more than five APs occur. In most experiments agonists and antagonists were applied via the bathing-solution. For some 
pharmacological experiments taurine, glycine, or isoguvacine was applied focally to the soma of the investigated cells via a patch pipette for 2-100 $\mathrm{ms}$ with a pressure of 0.4 bar using a pressure application system (LHDA0533115H, Lee, Westbrook, CT, USA).

\section{SOLUTIONS AND SUBSTANCES}

ACSF contained (in mM) $124 \mathrm{NaCl}, 26 \mathrm{NaHCO}_{3}, 1.25 \mathrm{NaH}_{2} \mathrm{PO}_{5}$, $1.8 \mathrm{MgCl}_{2}, 1.6 \mathrm{CaCl}_{2}, 3 \mathrm{KCl}, 20$ glucose (equilibrated with $95 \%$ $\mathrm{O}_{2} / 5 \% \mathrm{CO}_{2}$ ), osmolarity $333 \mathrm{mOsm}$ (determined by a freezing point osmometer, Knauer, Berlin, Germany). Standard pipette solution for whole-cell recordings contained (in $\mathrm{mM}$ ) $44 \mathrm{KCl}$, $80 \mathrm{~K}$-gluconate, $1 \mathrm{CaCl}_{2}, 2 \mathrm{MgCl}_{2}, 11$ ethylene glycol tetraacetic acid (EGTA), 10 4-(2-hydroxyethyl)-1-piperazineethanesulfonic acid (HEPES), $2 \mathrm{Na}_{2}$-ATP, $0.5 \mathrm{Na}-\mathrm{GTP}, \mathrm{pH}$ adjusted to 7.4 with $\mathrm{KOH}$ and osmolarity to $306 \mathrm{mOsm}$ with sucrose. For low- $\mathrm{Cl}^{-}$ pipette solution, the $\mathrm{KCl}$ concentration was reduced to $2 \mathrm{mM}$ and the K-Gluconate concentration raised to $124 \mathrm{mM}$. For cellattached recordings the pipette solution contained (in $\mathrm{mM}$ ) 126 K-Gluconate, $4 \mathrm{KCl}, 1 \mathrm{CaCl}_{2}, 2 \mathrm{MgCl}_{2}, 11 \mathrm{EGTA}, 10 \mathrm{HEPES}$, $2 \mathrm{Na}_{2}$-ATP, $0.5 \mathrm{Na}-\mathrm{GTP}, \mathrm{pH}$ adjusted to 7.4 with $\mathrm{KOH}$ and osmolarity to $306 \mathrm{mOsm}$ with sucrose.

Taurine was dissolved directly in ACSF, gabazine (SR-95531), 6-cyano-7-nitroquinoxaline-2,3-dione (CNQX) or strychnine were used from a stock solution in dimethylsulfoxide (DMSO), tetrodotoxin (TTX) from a stock solution in citrate buffer and glycine or $( \pm) \mathrm{R}(-)$-3-(2-carboxypiperazine-4-yl)-propyl-1phosphonic acid (CPP) from an aqueous stock solution. TTX was purchased from RBI (Natic, MA), glycine and taurine from Tocris (Ballwin, MO), and all other substances from Sigma. The final DMSO concentration never exceeded $0.5 \%$.

\section{STAINING PROCEDURES}

In all whole-cell experiments $0.5 \%$ biocytin (Sigma, Taufkirchen, Germany) was added to the pipette solutions to label the recorded neurons. Slices were fixed in a $4 \%$ parafolmaldehyde solution immediately after recording for more than $24 \mathrm{~h}$. After washing in phosphate buffer, slices were incubated in blocking solution (4\% normal goat and 3\% normal bovine serum, 0.5\% Triton, $0.05 \%$ sodium azide in phosphate buffered saline (PBS)) for $2 \mathrm{~h}$ at RT. Subsequently, biocytin-labeled neurons were stained with Cy-3 conjugated streptavidin (Dianova, Hamburg, Germany) as described in detail before (Achilles et al., 2007). Since the green fluorescent protein (GFP) fluorescence was not stable during the biocytin-streptavidin reaction, these slices were subsequently counterstained for GFP by incubating the slices with a GFP antibody raised in rabbit (1:500, Invitrogen, Karlsruhe, Germany) overnight at RT followed by a donkey anti-rabbit IgG secondary antibody conjugated with Dylight 488 (1:100; Dianova). Slices were embedded in fluoromount (Sigma). Immunofluorescence was investigated with a Nipkow spinning disk confocal system (Visitech, Sunderland, UK) attached to a conventional fluorescence microscope (Olympus BX51 WI) equipped with water immersion objectives and a cooled CCD-camera (CoolSnap HQ, Roper Scientific) controlled by MetaMorph software (Universal Imaging, West Chester, USA). Green and red fluorescence was excited with the $488 \mathrm{~nm}$ and the $568 \mathrm{~nm}$ lines of a Kr/Ar laser (Laser Physics, Malpas, UK).

\section{STATISTICS}

All values are expressed as mean \pm standard error of the mean (SEM). For statistical analysis Student $t$-test, Mann-Whitney$U$-test, ANOVA tests and Fishers Exact test were used (Systat 11, Systat Inc., Point Richmond, CA). Results were designated significant at a level of $p<0.05$.

\section{RESULTS \\ BASIC PROPERTIES OF THE INVESTIGATED CELLS}

In total 530 pyramidal neurons from P2-P4 mice pups identified by their location in the neocortex and their pyramidal like appearance in IR-DIC image were investigated using whole-cell patchclamp recordings (Figure 1A). These neurons had an average RMP of $-68.9 \pm 0.4 \mathrm{mV}(n=530)$, an input resistance of 1.7 $\pm 0.04 \mathrm{G} \Omega$ and an input capacity of $72.8 \pm 2.5 \mathrm{pF}$. In $96 \%$ of all 450 neurons investigated for this aspect APs with an average amplitude of $54.8 \pm 0.4 \mathrm{mV}(n=428)$ and duration of $4.4 \pm 0.08$ ms could be evoked upon a depolarization that crosses the APthreshold of $-41.7 \pm 0.3 \mathrm{mV}$ (Figure 1B).

In addition, $38 \mathrm{GFP}^{+}$GABAergic interneurons were recorded under whole-cell conditions (Figure 1C). These GABAergic interneurons had an average RMP of $-64.6 \pm 1.8 \mathrm{mV}(n=38)$, an input resistance of $3.3 \pm 0.3 \mathrm{G} \Omega$ and an input capacity of $37.2 \pm$ $5.0 \mathrm{pF}$. Injection of a depolarizing current evoked in these neurons APs with an amplitude of $37 \pm 1.8 \mathrm{mV}(n=35)$, a duration of 2.9 $\pm 0.3 \mathrm{~ms}$ and an AP-threshold of $-45.1 \pm 0.9 \mathrm{mV}$ (Figure 1D). Upon persistent injection of depolarizing currents these cell could discharge with a maximal frequency of $44.2 \pm 2.8 \mathrm{~Hz}(n=30)$, with a considerable heterogeneity.

\section{FOCAL TAURINERGIC RESPONSES}

To investigate the pharmacology of postsynaptic taurine responses, we first applied $5 \mathrm{mM}$ taurine directly to the soma of the recorded pyramidal cell. Focal taurine application (2-5 ms) induced in pyramidal neurons an inward current of $-260.4 \pm$ $31.9 \mathrm{pA}(n=12)$, which reversed at $-22.3 \pm 1.5 \mathrm{mV}(n=10$, Figure 2A), in accordance with the $\mathrm{Cl}^{-}$concentration of $50 \mathrm{mM}$ in the pipette solution. Bath application of $1 \mu \mathrm{M}$ strychnine significantly $(p<0.001)$ reduced the amplitude of taurineinduced currents by $80 \pm 5.2 \%(n=7$, Figures 2B, D). Bath application of $3 \mu \mathrm{M}$ gabazine reduced the amplitude of taurineinduced currents by $22 \pm 2.5 \%(n=8$, Figures $2 \mathrm{C}, \mathbf{D})$, and the combined application of $1 \mu \mathrm{M}$ strychnine and $3 \mu \mathrm{M}$ gabazine completely blocked taurine induced currents $(n=6$, Figure $2 \mathbf{B})$. Interestingly, in GABAergic interneurons the taurine-induced inward current of $154.8 \pm 22 \mathrm{pA}(n=10)$ was completely blocked by $1 \mu \mathrm{M}$ strychnine $(n=9)$, while $3 \mu \mathrm{M}$ gabazine $(n=8)$ had no effect ( $99.3 \pm 6.6 \%$; Figure 2E). In summary, these results suggest that the inward currents induced by high taurine concentrations were in pyramidal cells carried by both $\mathrm{GABA}_{\mathrm{A}}$ and glycine receptors, with the $\mathrm{GABA}_{\mathrm{A}}$ receptors mediating approximately $20 \%$ and glycine receptors approximately $80 \%$ of the responses, while in interneurons this current was exclusively mediated by glycine receptors.

As it had been shown that the pharmacological properties of glycine and $\mathrm{GABA}_{\mathrm{A}}$ receptors change during development (Aguayo et al., 2004; Carlson and Yeh, 2011), we next performed 


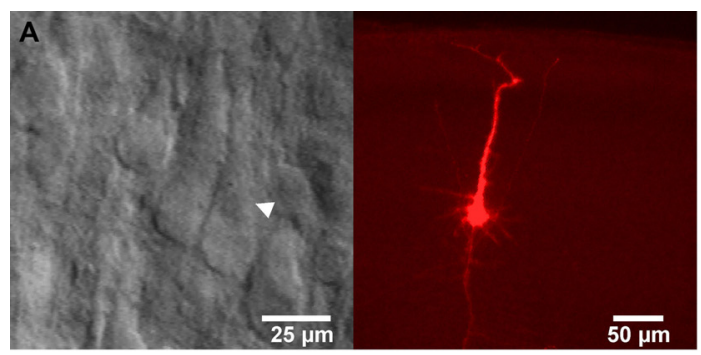

B
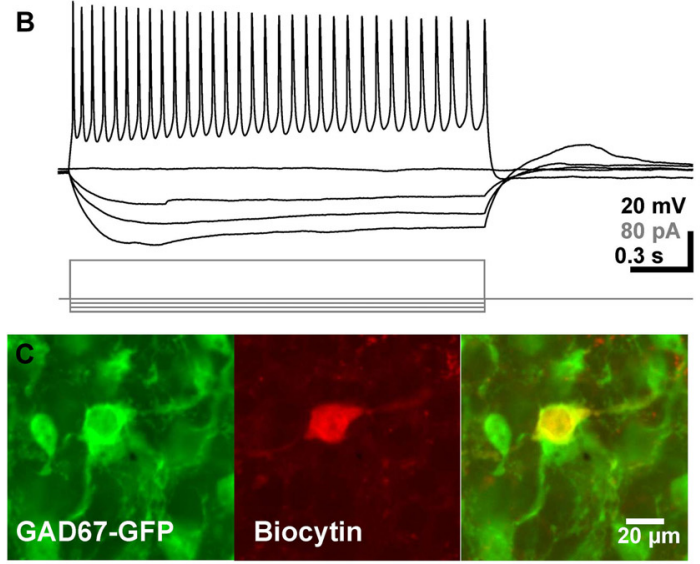

D

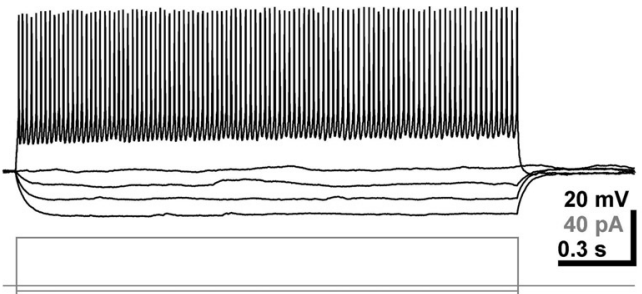

FIGURE 1 | Identification and basic electrophysiological properties of neocortical pyramidal neurons and GABAergic interneurons. (A) Typical interference contrast image of a pyramidal neuron (arrowhead in left image) and the same neuron after biocytin-labeling and subsequent histochemical processing. (B) Voltage-traces of the neuron shown in $\mathbf{A}$ upon injection of de- and hyperpolarizing current pulses. (C) Confocal fluorescence images displaying GFP-positive interneurons (left), a biocytin-labeled recorded neuron (middle) and the merged picture (right). (D) Representative voltage traces of a GABAergic interneuron. Note the high firing frequency in this recording.

control experiments to analyze the efficacy of strychnine and gabazine in immature pyramidal cells. In these experiments focal application of $100 \mu \mathrm{M}$ glycine induced an inward current of $180.2 \pm 42.5 \mathrm{pA}(n=9)$ that was completely blocked by $1 \mu \mathrm{M}$ strychnine $(n=6)$, while $3 \mu \mathrm{M}$ gabazine $(n=7)$ had no effect $(103 \pm 7.4 \%, n=7$, Figure $2 F)$. Focal application of the GABAergic agonist isoguvacine $(100 \mu \mathrm{M})$ induced an inward current of $382.3 \pm 37.9 \mathrm{pA}(n=7)$ that was completely blocked by $3 \mu \mathrm{M}$ gabazine $(n=6)$, while $1 \mu \mathrm{M}$ strychnine had no effect (99 $\pm 1.8 \%, n=4$, Figure 2G). Similar results were obtained in interneurons. Focal application of $100 \mu \mathrm{M}$ glycine induced in GABAergic interneurons a current of $91.4 \pm 21.2 \mathrm{pA}(n=$ 7 ) that was completely blocked by $1 \mu \mathrm{M}$ strychnine $(n=7)$, whereas $3 \mu \mathrm{M}$ gabazine had no effect $106.2 \pm 5.3 \%$ (Figure $2 \mathbf{H}$ ). Focal application of $100 \mu \mathrm{M}$ isoguvacine induced in GABAergic interneurons a current of $131.6 \pm 40.7 \mathrm{pA}(n=7)$ that was completely blocked by $3 \mu \mathrm{M}$ gabazine $(n=7)$, whereas $1 \mu \mathrm{M}$ strychnine had no effect $(96.3 \pm 3.8 \%$; Figure $2 \mathrm{I})$. These experiments demonstrate that $1 \mu \mathrm{M}$ strychnine and $3 \mu \mathrm{M}$ gabazine can be used as specific antagonists for glycine and $\mathrm{GABA}_{\mathrm{A}}$ receptors, respectively.

\section{EFFECT OF TAURINE ON SPONTANEOUS SYNAPTIC CURRENTS}

Bath application of taurine induced an inward current in pyramidal neurons. While taurine concentration $\leq 100 \mu \mathrm{M}$ did not elicit significant membrane currents (Figures 3A, C), inward currents of $17.3 \pm 0.8 \mathrm{pA}(n=258), 46.9 \pm 7.4(n=20)$ and $52 \pm$ $8.8 \mathrm{pA}(n=15)$ were induced by bath application of $300 \mu \mathrm{M}$, $1 \mathrm{mM}$ and $3 \mathrm{mM}$ taurine, respectively (Figures $3 \mathrm{~B}, \mathrm{C}$ ). The taurine-induced current showed a pronounced desensitization by $27.5 \pm 3.8 \%$ and $31.4 \pm 9 \%$ in $1 \mathrm{mM}$ and $3 \mathrm{mM}$ taurine, respectively, while no obvious desensitization occurred at lower taurine concentrations.

In addition to this inward current, bath application of taurine increased the frequency of PSCs in a considerable fraction of pyramidal neurons. While no significant effect was observed at taurine concentration $\leq 100 \mu \mathrm{M}$ (Figures $3 \mathrm{~A}, \mathrm{C}$ ), in $46.8 \%$ (133 out of 275 cells) of all investigated neurons bath application of $300 \mu \mathrm{M}$ taurine induced an increase in the frequency of PSCs (Figure 3B). In 125 of these cells a significant ( $>4 \mathrm{x}$ SD of control) increase of PSC frequency by $815 \pm 86 \%$ from $0.16 \pm 0.02 \mathrm{~Hz}$ $(n=138)$ to $0.59 \pm 0.05 \mathrm{~Hz}(n=125$, Figure $3 \mathrm{D})$ was induced. In the eight additional neurons that showed PSCs during taurine application, PSCs were absent during the control interval. The majority $(91.5 \%)$ of the remaining 142 neurons did no show PSCs neither before nor in the presence of $300 \mu \mathrm{M}$ taurine, while in 12 neurons no significant increase in PSC frequency (between 89 and $229 \%$ of control) was observed in the presence of $300 \mu \mathrm{M}$ taurine. The frequency of taurine-induced PSCs showed no significant correlation $\left(r^{2}=0.17\right)$ with the PSC frequency during the control interval. In addition, the amplitude of PSCs increased from $19.3 \pm 1 \mathrm{pA}(n=137)$ to $24.6 \pm 1.3 \mathrm{pA}(n=$ 145 ) in the presence of $300 \mu \mathrm{M}$ taurine. Furthermore, increasing the taurine concentration to $1 \mathrm{mM}$ or $3 \mathrm{mM}$ induced comparable effects on PSCs. Bath application of $1 \mathrm{mM}$ taurine increased the frequency of PSCs in 10 out of 21 investigated neurons by $694 \pm$ $210 \%$, while $3 \mathrm{mM}$ taurine increased the frequency in 6 out of 15 neurons and $518 \pm 198 \%(n=7$, Figure 3D $)$. Neither the amplitude nor the frequency was significantly different from the effects of $300 \mu \mathrm{M}$ taurine, indicating that $300 \mu \mathrm{M}$ taurine was sufficient to provoke a maximal effect on PSCs. Therefore we performed all subsequent experiments with $300 \mu \mathrm{M}$ taurine. To test if taurine responses are stable during repetitive applications we applied $300 \mu \mathrm{M}$ taurine for three times to the same cell. These experiments revealed no significant differences in taurineinduced inward currents (Figure 3E) as well as in amplitude and frequency of taurine-induced PSCs between the first, second and third taurine application (Figure 3F). In summary, these results show that bath application of taurine at a concentration $\geq 300 \mu \mathrm{M}$ increased the frequency of the PSCs in about half of all pyramidal neurons, suggesting that activity of GABAergic synapses was considerably increased by taurine. 

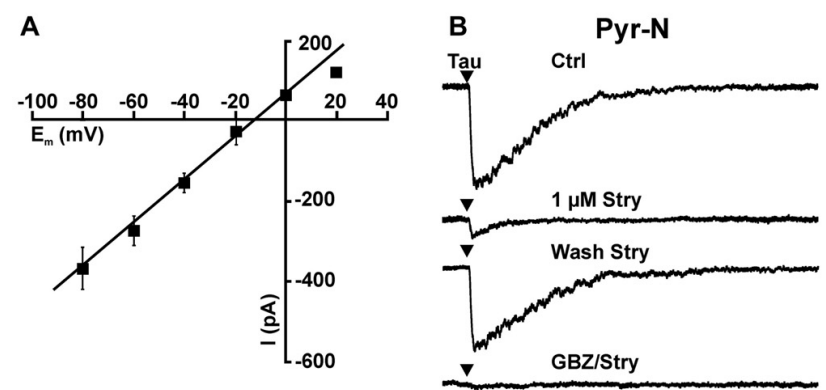

D

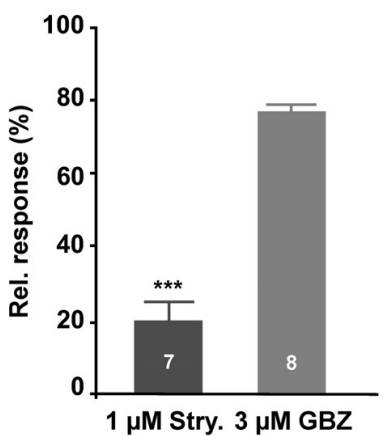

E

GABA-IN

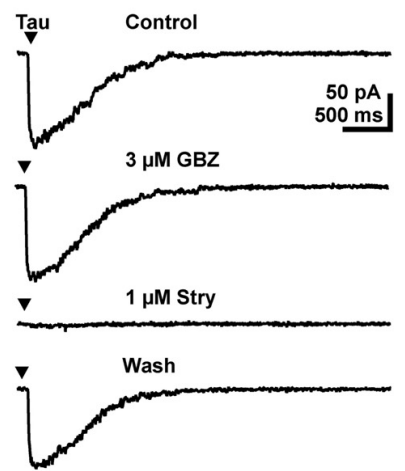

$\mathbf{F}$

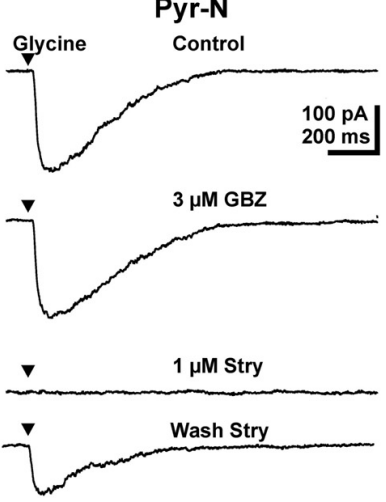

H

GABA-IN
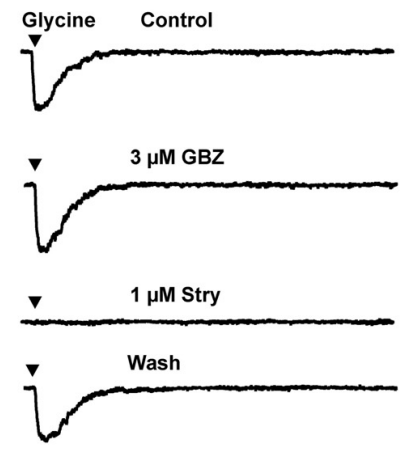

C Pyr-N

Tau Control

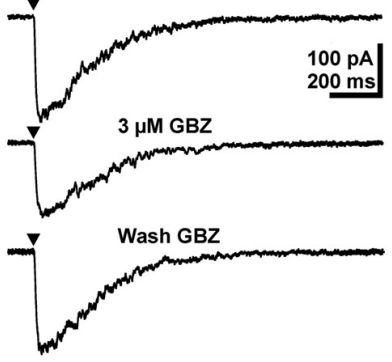

G

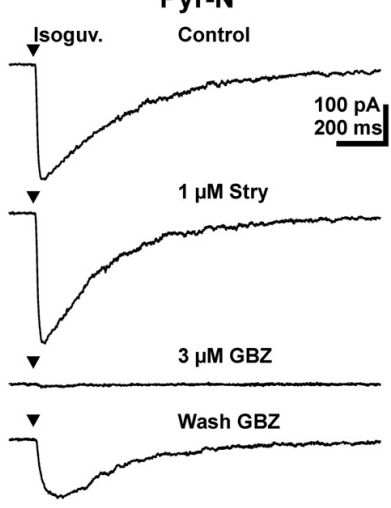

I
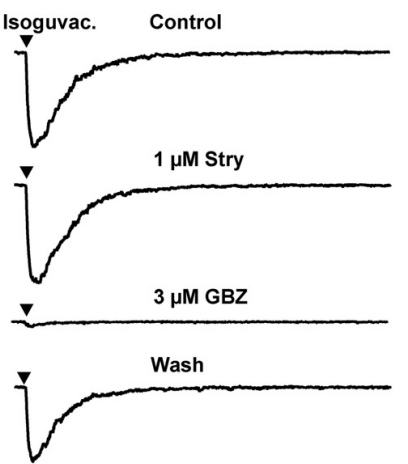

FIGURE 2 | Activation of $\mathrm{GABA}_{A}$ and glycine receptors by focal application of $5 \mathrm{mM}$ taurine in pyramidal neurons and GABAergic

interneurons. (A) Current-voltage (I-V) plot of the inward current after focal application of $5 \mathrm{mM}$ taurine at different voltages. Note the linear I-V relation and that the current reversed close to the estimated reversal potential. (B) Inward currents elicited by a $5 \mathrm{~ms}$ application of $5 \mathrm{mM}$ taurine (Tau) are reduced in the presence of $1 \mu \mathrm{M}$ strychnine (Stry). After a partially washout of strychnine, combined application of $3 \mu \mathrm{M}$ gabazine (GBZ) and $1 \mu \mathrm{M}$ strychnine completely suppressed the taurine-induced current. (C) Inward currents elicited by $5 \mathrm{mM}$ taurine are slightly reduced in the presence of $3 \mu \mathrm{M}$ GBZ. (D) Statistical analysis of these experiments. Bars represent mean \pm SEM of maximal inward current amplitudes. (E) In GABAergic interneurons, focal application of $5 \mathrm{mM}$ taurine induced an inward current that is unaffected by $3 \mu \mathrm{M} \mathrm{GBZ}$ and completely blocked in the presence of $1 \mu \mathrm{M}$ strychnine. (F) In pyramidal neurons focal application of $100 \mu \mathrm{M}$ glycine induced an inward current that was unaffected in the presence of $3 \mu \mathrm{M} \mathrm{GBZ}$ and completely blocked in the presence of strychnine. (G) In pyramidal neurons focal application of $100 \mu \mathrm{M}$ isoguvacine induced an inward current that was unaffected by strychnine and completely blocked in the presence of GBZ. (H) In GABAergic interneurons focal application of $100 \mu \mathrm{M}$ glycine induced an inward current that was unaffected by GBZ, but completely blocked in the presence of strychnine. (I) In GABAergic interneurons focal application of $100 \mu \mathrm{M}$ isoguvacine induced an inward current that was completely blocked by GBZ, but unaffected in the presence of strychnine.
PHARMACOLOGY OF TAURINE-INDUCED RESPONSES IN PYRAMIDAL NEURONS

Next we analyzed the pharmacological properties of the PSCs evoked by the bath application of $300 \mu \mathrm{M}$ taurine.
Bath-application of TTX inhibited the taurine-induced PSCs (Figure 4A). In the presence of $0.2-1 \mu \mathrm{M}$ TTX bath application of $300 \mu \mathrm{M}$ taurine fails to increase the frequency (101.6 \pm $14.3 \%, n=6)$ and amplitude $(97.4 \pm 5 \%)$ of PSCs. In 
A
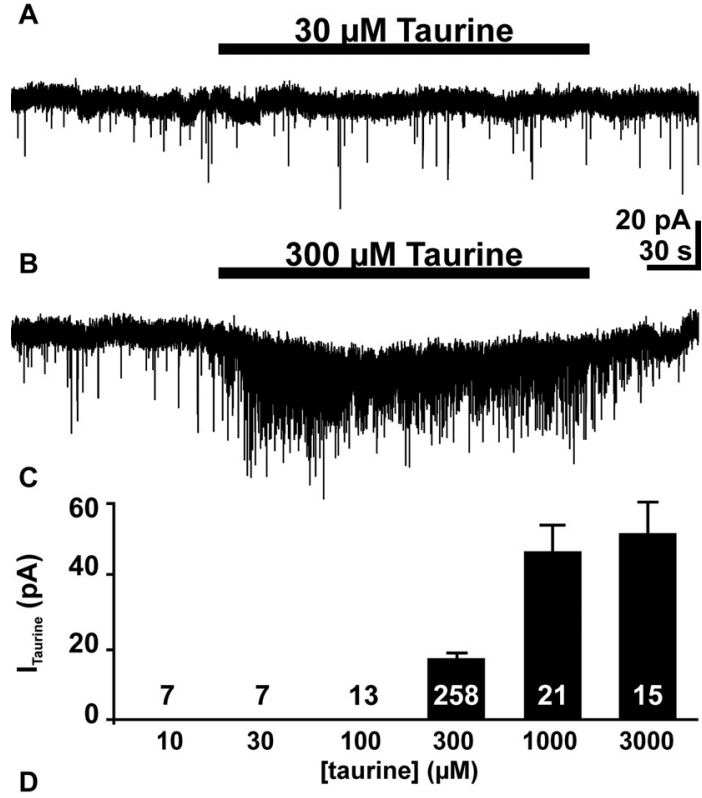

D

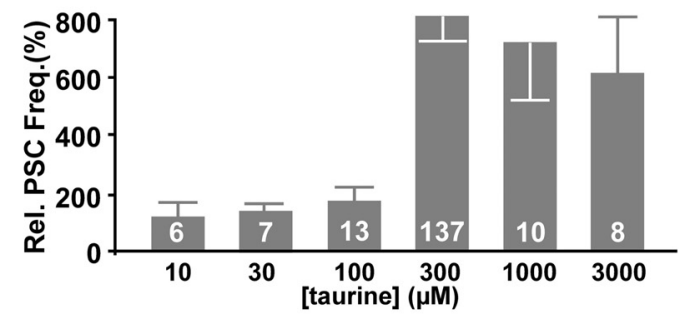

E

$\mathbf{F}$
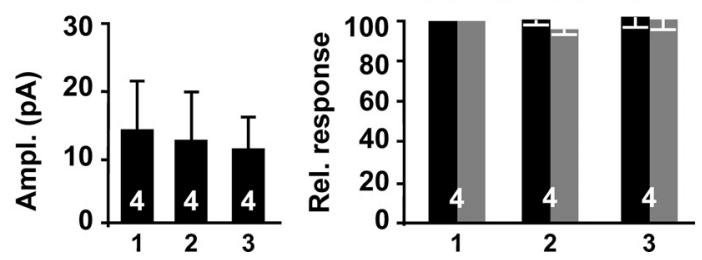

FIGURE 3 | The effect of bath-applied taurine on pyramidal neurons (A) Whole-cell voltage-clamp recording from a pyramidal neuron. Bath application of $30 \mu \mathrm{M}$ taurine did not affect the holding current or the frequency of the PSCs. (B) Bath application of $300 \mu \mathrm{M}$ taurine induced an inward current and a massive increase in the frequency of PSCs. (C) Statistical analysis of inward current amplitudes induced by different taurine concentration. (D) Statistical analysis of relative PSC frequency (normalized to control intervals) in the presence of different taurine concentrations. Note that the effect of taurine on PSC frequency displays a clear threshold behavior. (E, F) Neither the amplitude of the inward current (E), nor amplitude (black bars) and frequency (gray bars) of taurine-induced PSCs differ significantly in three consecutive applications. Bars represent mean \pm SEM, number of experiments is given in the bars.

three additional TTX-treated slices that did not show spontaneous PSCs under control conditions, $300 \mu \mathrm{M}$ taurine failed to evoke PSCs. The taurine-induced inward current was, however, not significantly affected under this condition $(137 \pm 25.1 \%$, $n=9)$. These observations suggest that the taurine-induced increase in PSC frequency requires the activation of presynaptic networks.

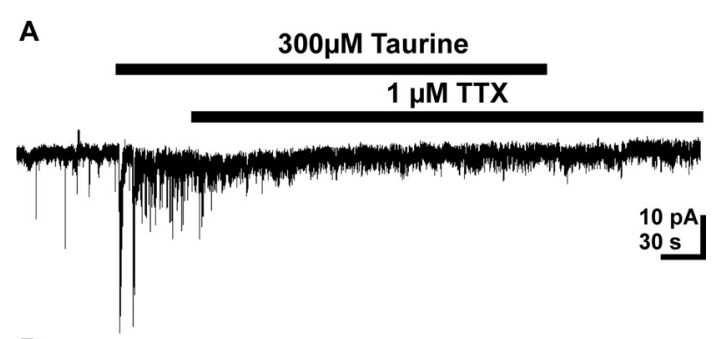

B

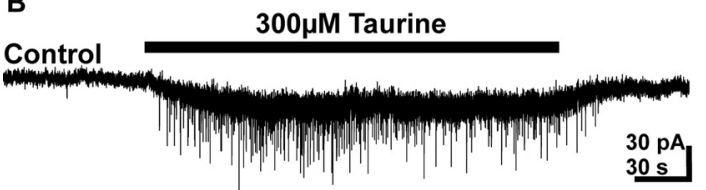

in CPPICNQX

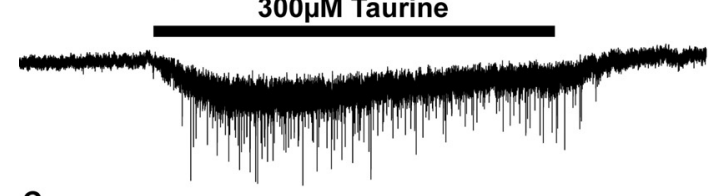

C

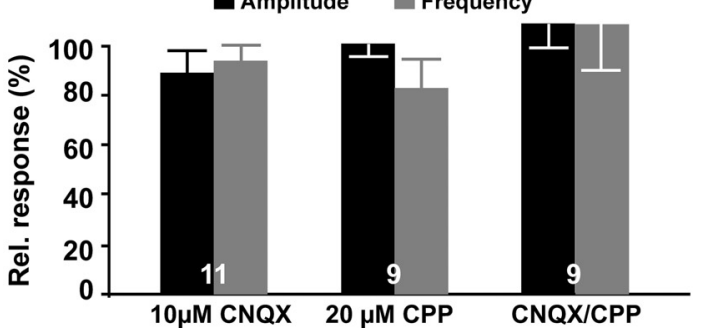

FIGURE 4 | Pharmacology of taurine responses. (A) Typical current registration illustrating that taurine-induced increase in the PSC frequency was suppressed in the presence of $1 \mu \mathrm{M}$ TTX. (B) Typical current registration illustrating that the taurine-induced increase in PSCs frequency was not affected in the presence of $10 \mu \mathrm{M}$ CNOX 6-cyano-7nitroquinoxaline-2,3-dione (CNOX) $+20 \mu \mathrm{M}( \pm)$

R(-)-3-(2-carboxypiperazine-4-yl)-propyl-1-phosphonic acid (CPP). (C) Statistical analysis of the effect of glutamatergic antagonists on relative frequency and amplitude of taurine-induced PSCs. Bars represent mean \pm SEM, numbers of experiments are given in the bars.

Inhibition of ionotropic glutamate receptors by bath application of $10 \mu \mathrm{M}$ CNQX or $20 \mu \mathrm{M}$ CPP had no significant effect on the taurine-induced PSCs. In the presence of both glutamate antagonists neither amplitude $(27.13 \pm 3$ vs. $31.6 \pm$ $6.3 \mathrm{pA})$ nor the frequency $(0.55 \pm 0.09$ vs. $0.55 \pm 0.11 \mathrm{~Hz})$ of taurine-induced PSCs was significantly ( $p=0.5$ and $p=1$, respectively, $n=9$ ) different from the control application in ACSF (Figures 4B, C). The taurine-induced inward current was also unaffected under this condition $(15.9 \pm 2.1$ vs. $17.7 \pm 4.3 \mathrm{pA}$, $n=9)$. Similar results were obtained if these glutamate receptor antagonists were applied alone (Figure 4C). These results suggest that glutamatergic synapses are not activated by bath application of taurine. These experiments also revealed that the frequency of spontaneous postsynaptic events (sPSCs) was not significantly reduced in the presence of $10 \mu \mathrm{M} \mathrm{CNQX}$ and $20 \mu \mathrm{M}$ CPP (128 \pm $40 \%, n=9$ ).

On the other hand, bath application of the $\mathrm{GABA}_{\mathrm{A}}$ receptor antagonist gabazine $(3 \mu \mathrm{M})$ completely blocked sPSCs in 19 
A

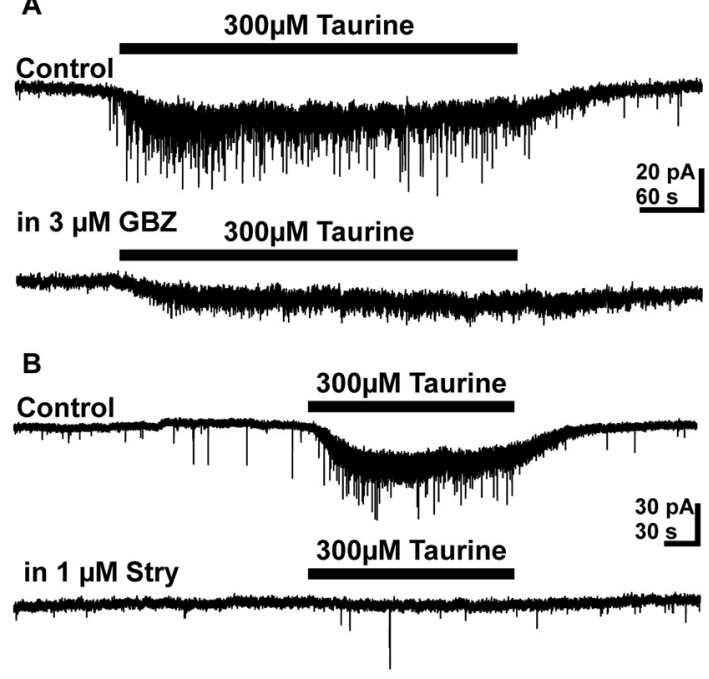

FIGURE 5 | Effect of GABA $A_{A}$ and glycine receptor antagonists on taurine induced responses. (A) Typical current traces illustrating that $3 \mu \mathrm{M}$ gabazine (GBZ) abolished the taurine-induced increase in PSC frequency and reduced the amplitude of the taurine-induced inward current. (B) Typical current traces illustrating that $1 \mu \mathrm{M}$ strychnine abolished the taurine-induced increase in PSC frequency and reduced the amplitude of the taurine-induced inward current.

out of 26 pyramidal cells investigated and massively reduced the frequency of sPSCs to $0.023 \pm 0.007 \mathrm{~Hz}$ in the remaining seven neurons. This result indicates that the majority of sPSCs is mediated by $\mathrm{GABA}_{\mathrm{A}}$ receptors. Bath application of $300 \mu \mathrm{M}$ taurine in the presence of $3 \mu \mathrm{M}$ gabazine did not induce a significant $(p=0.34)$ increase in frequency of PSCs $(0.06 \pm$ $0.02 \mathrm{~Hz}, n=5$, Figure 5A), suggesting that $\mathrm{GABA}_{\mathrm{A}}$ receptors are required for this taurine effect. The taurine-induced inward current was significantly $(p<0.001)$ reduced by $79.6 \pm 8.3 \%$ $(n=8)$ from $21 \pm 2.6$ to $5.6 \pm 2.5 \mathrm{pA}$ in the presence of gabazine.

Bath application of the glycine receptor antagonist strychnine (0.3-1 $\mu \mathrm{M})$ had no significant effect on frequency $(107 \pm 15 \%$, $n=12)$ and amplitude $(92 \pm 11 \%)$ of sPSCs, supporting previous reports that glycine receptors are not directly involved in synaptic transmission in the developing neocortex (Flint et al., 1998; Okabe et al., 2004; Kilb et al., 2008). However, in the presence of $0.3-1 \mu \mathrm{M}$ strychnine the taurine-induced increase in PSC frequency was completely suppressed (Figure 5B). Under this condition bath application of taurine had no effect on the frequency $(0.11 \pm 0.01$ vs. $0.11 \pm 0.02 \mathrm{~Hz}, n=12)$ and amplitude (13.84 \pm 0.9 vs. $16.3 \pm 2.4 \mathrm{pA}, n=12)$ of PSCs. In addition, the taurine-induced inward current was significantly $(p<0.001)$ reduced by $47.7 \pm 8.3 \%(n=12)$ from $22.2 \pm 2.8$ to $9.7 \pm 1.1 \mathrm{pA}$. In the presence of both, $1 \mu \mathrm{M}$ strychnine and $3 \mu \mathrm{M}$ gabazine the taurine-induced inward current was massively reduced by $95.5 \pm 1.2 \%$ to $1.1 \pm 0.4 \mathrm{pA}(n=12)$. Under this condition bath application of $300 \mu \mathrm{M}$ taurine did also not increase the frequency of PSCs ( $0.03 \pm 0.004$ vs. $0.03 \pm 0.002, n=8)$. In summary, these results suggest that glycine receptors are essential for the presynaptic taurine effect and also contribute to the postsynaptic taurinergic currents.

Since the previous results indicate that taurine acting tonically on presynaptic glycine receptors enhance the frequency of putative GABAergic PSCs, we next directly stimulated presynaptic $\mathrm{GABA}_{\mathrm{A}}$ and glycine receptors. These experiments were performed in the presence of $10 \mu \mathrm{M}$ CNQX and $20 \mu \mathrm{M}$ CPP to isolate GABAergic PSCs. Tonic activation of $\mathrm{GABA}_{\mathrm{A}}$ receptors by bath application of $3 \mu \mathrm{M}$ isoguvacine induced an inward current of $19.8 \pm 5.3 \mathrm{pA}(n=8)$. In addition, it increased the frequency of PSCs by $566 \pm 219 \%$ from $0.1 \pm 0.04$ to $0.24 \pm$ $0.05 \mathrm{~Hz}(n=8$, Figure 6A). This result indicates that tonic activation of presynaptic $\mathrm{GABA}_{\mathrm{A}}$ receptors is sufficient to enhance GABAergic inputs to pyramidal cells. Bath application of $100 \mu \mathrm{M}$ glycine induced an inward current of $14.1 \pm 4.8 \mathrm{pA}(n=6)$ and increased the frequency of PSCs in 4 out of 6 investigated pyramidal neurons by $1045 \pm 831 \%(n=4$, Figure 6B $)$ and induced in the remaining two neurons, which did not showed more than two PSCs in the control interval, a burst of PSCs. The frequency of glycine-induced PSCs was $0.47 \pm 0.19 \mathrm{~Hz}(n=6)$. To prove that these glycine-induced PSCs were indeed mediated by $\mathrm{GABA}_{\mathrm{A}}$ receptors in the postsynaptic membrane, we next applied $100 \mu \mathrm{M}$ glycine in the continuous presence of $3 \mu \mathrm{M}$ gabazine, $10 \mu \mathrm{M}$ CNQX and $20 \mu \mathrm{M}$ CPP. Under this condition spontaneous PSCs were absent and bath application of $100 \mu \mathrm{M}$ glycine did not induce PSCs $(n=6$, Figure 6C), suggesting that glycine application enhanced exclusively GABAergic PSCs. In summary, these results indicate that activation of presynaptic glycine but also $\mathrm{GABA}_{\mathrm{A}}$ receptors can increase the frequency of GABAergic PSCs.

\section{TAURINE INDUCED GABAergic POSTSYNAPTIC CURRENTS (PSCs) THAT MEDIATE EXCITATORY RESPONSES}

To strengthen our previous suggestion, that $\mathrm{GABA}_{\mathrm{A}}$ receptors are underlying the taurine-induced PSCs in pyramidal neurons, we next determined the reversal potential $\left(E_{\mathrm{Rev}}\right)$ of these PSCs. For this purpose we performed voltage-clamp experiments using a pipette-solution with a $\mathrm{Cl}^{-}$concentration of $8 \mathrm{mM}$, which corresponds to an $E_{\mathrm{Rev}}$ of $-62.5 \mathrm{mV}$. In these experiments the cell was clamped exactly to $E_{\mathrm{Rev}}$, which was determined experimentally for each cell by a series of focal GABA pulses at different holding potentials. These experiments revealed that the frequency of sPSCs was reduced to from $0.042 \pm 0.013 \mathrm{~Hz}(n=7)$ to $0.021 \pm 0.006 \mathrm{~Hz}(n=7)$ if the membrane was clamped from $-85 \mathrm{mV}$ to $E_{\mathrm{Rev}}$, indicating that a substantial fraction of sPSCs is mediated by ligand-gated $\mathrm{Cl}^{-}$channels. At this holding potential bath application of $300 \mu \mathrm{M}$ taurine had no significant $(p=0.35)$ effect on the frequency of PSCs (77 $\pm 15 \%, n=5$, Figure 7A). In contrast, under conditions when the holding potential was negative $(-85 \mathrm{mV})$ or positive $(0 \mathrm{mV})$ to $E_{\mathrm{Rev}}$ bath application of $300 \mu \mathrm{M}$ taurine significantly increased the frequency of PSCs to $454 \pm 70 \%(n=7)$ and $630 \pm 149 \%(n=11)$, respectively, indicating that taurine initiates PSCs that are mediated via ligand-gated $\mathrm{Cl}^{-}$channels. Accordingly the taurine-induced PSCs reversed at $-56.7 \mathrm{mV}$, approximately at the estimated $E_{\mathrm{Rev}}$ (Figure 7B).

As many studies indicate that an activation of $\mathrm{GABA}_{\mathrm{A}}$ receptors mediate depolarizing membrane responses in immature 


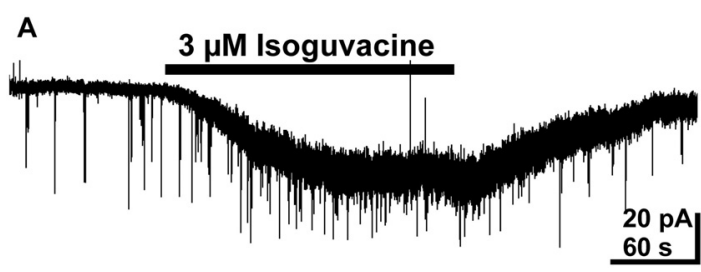

B

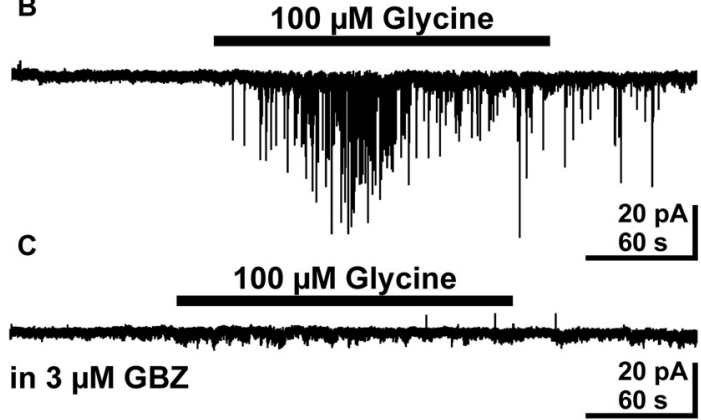

FIGURE 6 | Effect of bath applied isoguvacine and glycine on pyramidal neurons in the presence of $10 \mu \mathrm{M}$ CNOX and $20 \mu \mathrm{M}$ CPP. (A) Typical current recording demonstrating that bath application of $3 \mu \mathrm{M}$ isoguvacine induced an inward current and increased the PSC frequency. (B) Typical trace illustrating that bath application of $100 \mu \mathrm{M}$ glycine increased the frequency of PSCs. (C) In the subsequent recording from the same neuron as in $\mathbf{B}$ the PSCs induced by bath application of $100 \mu \mathrm{M}$ glycine are completely suppressed in the presence of $3 \mu \mathrm{M}$ gabazine (GBZ).

neocortical neurons (Owens et al., 1996; Achilles et al., 2007; Kolbaev et al., 2011b), we next investigated whether taurineinduced membrane responses mediate excitatory actions under physiological conditions. Therefore we performed cell-attached recordings to investigate this effect under conditions in which the intracellular $\mathrm{Cl}^{-}$concentration $\left(\left[\mathrm{Cl}^{-}\right]_{i}\right)$ remained undisturbed. In 28 out of 35 investigated neurons spontaneous APs at a frequency of $0.29 \pm 0.9 \mathrm{~Hz}(n=28)$ were observed, the remaining eight cells showed less that three APs during the control interval. Bath application of $300 \mu \mathrm{M}$ taurine increased the AP frequency in 20 (corresponding to $57 \%$ ) of these neurons by more than $50 \%$ to $0.68 \pm 0.16 \mathrm{~Hz}$ (Figure 7B). In 15 of the cells the AP frequency was sufficiently high $(>0.15 \mathrm{~Hz}$, corresponding to $>25$ spikes per control interval) to estimate possible inhibitory action. However, in only 3 of these 15 cells bath-application of taurine reduced AP frequency. In order to unravel, whether the taurineinduced increase in AP frequency was caused by GABAergic PSCs or the depolarizing inward current, we next applied $300 \mu \mathrm{M}$ taurine in the presence of low gabazine concentrations, which selectively inhibit phasic GABAergic currents (Stell and Mody, 2002; Kolbaev et al., 2012). Accordingly we were able to show that bath application of $0.3 \mu \mathrm{M}$ gabazine completely blocked the taurine-induced increase in the frequency of GABAergic PSCs $(n=7)$, while the tonic current was not significantly affected (94.9 $\pm 16.3 \%, n=7)$. Cell-attached recordings revealed that in the presence of $0.3 \mu \mathrm{M}$ gabazine bath application of $300 \mu \mathrm{M}$ taurine had no effect on AP frequency in 12 investigated cells, which all revealed a taurine-induced increase in AP frequency under control conditions (Figure 7C). These results strongly suggest

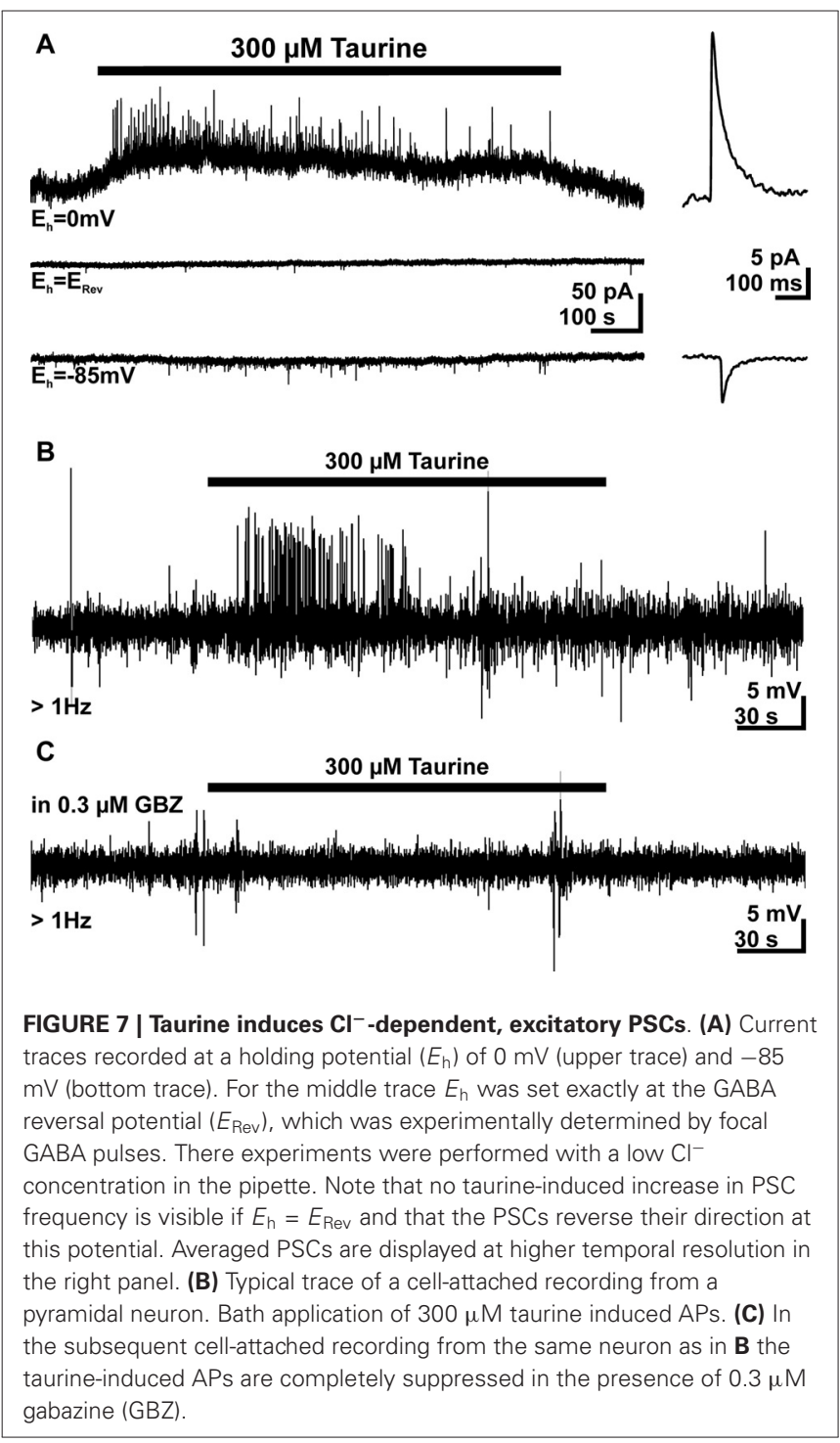

that the taurine-induced PSCs are GABAergic and mediate an excitatory action on pyramidal neurons.

\section{EFFECT OF TAURINE ON GABAergic INTERNEURONS}

Since the previous results demonstrated that taurine enhanced the frequency of GABAergic PSCs, we next analyzed the effect of taurine on GABAergic interneurons. Therefore we performed whole-cell and cell-attached measurements on GABAergic interneurons identified by GFP expression under the control of GAD67 (Tamamaki et al., 2003). The whole-cell experiments revealed that bath application of $300 \mu \mathrm{M}$ taurine induced an inward current of $10.6 \pm 2.2 \mathrm{pA}(n=14)$. This inward current was significantly attenuated by $49 \pm 8 \%(n=6, p=0.0313)$ in the presence of $3 \mu \mathrm{M}$ gabazine and by $70 \pm 13 \%(n=7, p=0.0156)$ in the presence of $1 \mu \mathrm{M}$ strychnine (Figures $\mathbf{8 A}, \mathbf{B}$ ). In summary, these results indicate that taurine mediates a tonic activation of glycine receptors and to a lesser extent of $\mathrm{GABA}_{\mathrm{A}}$ receptors in these cells.

To analyze whether this taurine-induced inward current mediates an excitatory effect under conditions with undisturbed 


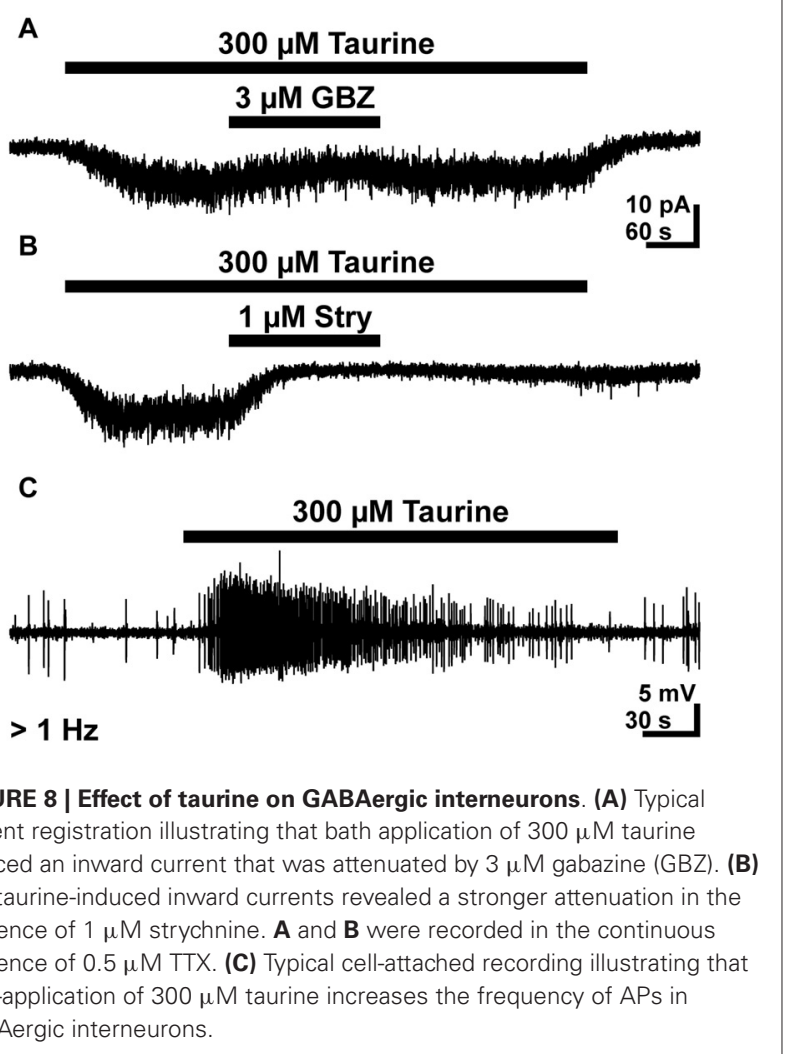

$\left[\mathrm{Cl}^{-}\right]_{i}$, we next performed cell-attached experiments. These experiments revealed that bath application of $300 \mu \mathrm{M}$ taurine induced in 17 out of 30 investigated GABAergic interneurons (corresponding to 56.7\%) a significant $(p<0.001)$ increase in AP frequency from $0.1 \pm 0.02$ to $1.1 \pm 0.27 \mathrm{~Hz}$ (Figure 8C). In summary, these results demonstrate that bath application of $300 \mu \mathrm{M}$ taurine excites a considerably fraction of GABAergic interneurons and that this activity is mediated mainly via glycine receptors.

Finally, we investigated whether SP cells, which are comprised of a significant fraction of GABAergic neurons (Kanold and Luhmann, 2010) and are activated by taurine (Kilb et al., 2008), contribute to GABAergic taurine-induced PSCs. For this purpose we used a reduced neocortical slice preparations either containing or lacking the SP (Figure 9A). In both preparations bath application of $300 \mu \mathrm{M}$ taurine induced PSC activity. In reduced slices that contained the SP, taurine increased the frequency of PSCs by $531 \pm 138 \%(n=4)$ to $0.19 \pm 0.02 \mathrm{~Hz}$. A comparable effect was observed in slices without SP, in which the frequency of PSCs increased by $697 \pm 170 \%(n=6)$ to $0.26 \pm 0.05 \mathrm{~Hz}$ (Figure 9B). The taurine-induced PSCs had comparable amplitudes in both preparations (14.4 \pm 1.9 vs. 18.8 $\pm 1.8 \mathrm{pA}$ ). In summary, these results suggest that GABAergic SP neurons do not contribute substantially to the taurine-induced activity.

\section{DISCUSSION}

The main findings of this study can be summarized as follows: (i) bath application of $300 \mu \mathrm{M}$ taurine increased the frequency
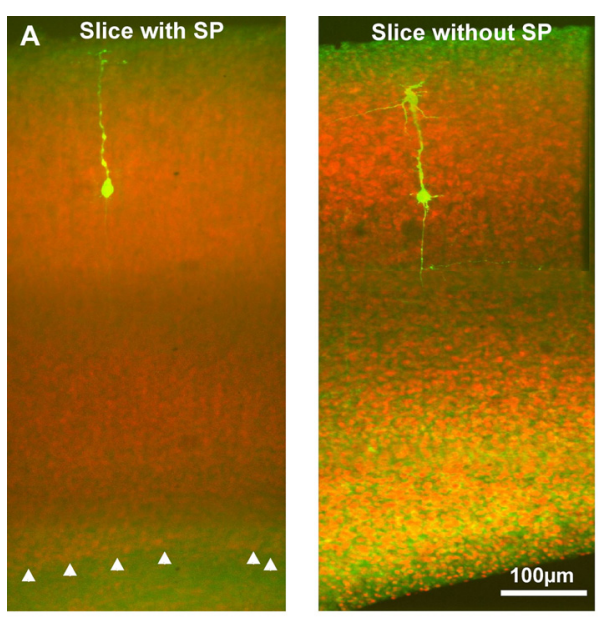

B

Slice without SP

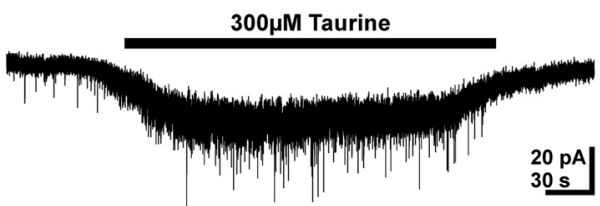

FIGURE 9 | Taurine effect on pyramidal neurons in reduced slice preparation. (A) Confocal images of biocytin-labeled neurons (green) counter-stained with propidium jodide. Note the absence of the SP (white arrowheads) in the right slice. (B) Typical current registration illustrating that bath application of taurine increased the frequency of PSCs in a reduced slice preparation without SP.

of PSCs in a considerable fraction of pyramidal neurons; (ii) taurine, but also glycine and isoguvacine specifically increased the frequency of $\mathrm{GABA}_{\mathrm{A}}$ receptor mediated PSCs; (iii) these taurine-induced GABAergic PSCs mediated an excitatory effect; (iv) taurine, acting mainly on glycine receptors, induced an inward current and repetitive APs in GABAergic interneurons; and (v) GABAergic SP neurons do not substantially contribute to the taurine-induced activity. We conclude from these results that taurine can enhance the activity of excitatory GABAergic networks in the immature neocortex.

Passive and active membrane properties of the pyramidal neurons from $\mathrm{P} 2-\mathrm{P} 4$ mice are in accordance with previous results (Kriegstein et al., 1987; Luhmann et al., 2000; Picken Bahrey and Moody, 2003; Okabe et al., 2004). The passive membrane properties of the immature GABAergic interneuron as well as the relatively low maximal firing frequency of these neurons are in line with the developmental profile of immature interneurons (Doischer et al., 2008; Okaty et al., 2009).

One major conclusion of our study is that taurine specifically increased the frequency of GABAergic PSCs. Several lines of evidence support this hypothesis. First, the taurine-mediated increase in PSC frequency was unaffected by glutamatergic antagonists but completely suppressed by the $\mathrm{GABA}_{\mathrm{A}}$ receptor antagonist gabazine. This finding may be explained by the hypothesis that $\mathrm{GABA}_{\mathrm{A}}$ receptor activation on presynaptic cells is required for the activation of the PSCs, but the observation that 
bath-application of glycine induced a similar gabazine-sensitive increase in PSC frequency suggests that a taurine-mediated glycine receptor activation is sufficient to induce these PSCs. Second, the taurine-induced PSCs reversed around $E_{\mathrm{Cl}}$, which would, however, also match to a glycinergic neurotransmission. But the observation that the glycine-induced increase in PSC frequency was completely blocked by gabazine indicates that under this condition only GABAergic PSCs were induced and suggests that this is also the case for the taurine-induced PSCs. These suggestions are supported by the observation that an adequate glycinergic stimulation of presynaptic cells is required to provoke taurine-induced PSCs. And finally, the observation that a specific inhibition of synpatically $\mathrm{GABA}_{\mathrm{A}}$ receptors by low gabazine concentrations completely abolished the taurine-induced PSCs also indicates that these PSCs were GABAergic. In summary, these results strongly suggest that bath-application of taurine, but also of glycine or isoguvacine, selectively activated GABAergic PSCs.

A variety of previous studies demonstrated that activation of $\mathrm{GABA}_{\mathrm{A}}$ receptors mediate depolarizing membrane responses in immature neurons, due to the high $\left[\mathrm{Cl}^{-}\right]_{i}$ in these cells (Owens et al., 1996; Achilles et al., 2007; Ben-Ari et al., 2012). Although such depolarizing responses do not necessarily enhance the excitability of neurons (Jedlicka et al., 2011; Kolbaev et al., 2011a), our observation that under cell-attached conditions taurine can induce barrages of APs, which are abolished by a specific inhibition of synaptic GABAergic currents with a low dose of gabazine, convincingly demonstrate that these synaptic GABAergic inputs mediate an excitation of immature pyramidal neurons. This is in line with previous publications which reported that in the immature neocortex GABAergic inputs from the zona incerta can mediate excitatory responses in pyramidal neurons (Dammerman et al., 2000) and that in immature GABAergic interneurons and Cajal-Retzius cells GABAergic synaptic inputs reliably trigger APs (Rheims et al., 2008; Cosgrove and Maccaferri, 2012).

Theoretically, the GABAergic PSCs can rely on an increased spontaneous release probability of GABA vesicles or from an excitation of presynaptic GABAergic interneurons (Hessler et al., 1993; Kirmse and Kirischuk, 2006). However, as the taurineinduced increase in PSCs frequency was absent in the presence of TTX, these PSCs reflect an increased activity of GABAergic interneurons rather than an increased release probability of presynaptic neurotransmitter vesicles. Accordingly, we were able to directly demonstrate that taurine induced an inward current in GABAergic interneurons, which is in 56\% of these neurons sufficient to trigger APs. Interestingly the frequency of the APs is higher than the frequency of the taurine-induced PSCs in pyramidal neurons, suggesting a high failure rate and/or synaptic fatigue in these GABAergic synapses, but probably also that only few GABAergic interneurons make synaptic contacts to pyramidal neurons at this age. The taurinergic inward current in GABAergic interneurons was mimicked by bath application of glycine and isoguvacine, indicating that both $\mathrm{GABA}_{\mathrm{A}}$ and glycine receptors can potentially contribute to the taurine effect. The puzzling observation that in interneurons strychnine abolished responses to focal taurine application, while the tonic current mediated by bath applied taurine was only reduced by $70 \%$, may be caused by distinct activation kinetics of glycine and GABA receptors upon fast application and by a differential desensitization of both receptors in the continuous presence of taurine. While $\mathrm{GABA}_{\mathrm{A}}$ receptors had already been described in immature interneurons (Gozlan and Ben-Ari, 2003), no evidences for glycine receptors on cortical interneurons were reported so far. The observations that strychnine completely blocked focal taurine responses and suppressed bath-applied responses by $70 \%$, while gabazine had a lower efficiency, suggest that taurine exerts its effect on GABAergic interneurons mainly via glycine receptors. Accordingly, the taurine-induced GABAergic PSCs were abolished in the presence of strychnine, illustrating that a taurinergic activation of only $\mathrm{GABA}_{\mathrm{A}}$ receptors was insufficient to activate the presynaptic GABAergic networks.

The subtype of the GABAergic interneurons that mediate these excitatory synaptic inputs could not be defined in our study. We can exclude that a GABAergic population of SP neurons (Hanganu et al., 2002; Luhmann et al., 2009; Kanold and Luhmann, 2010) is a major source of the taurine-induced GABAergic PSCs, since we could demonstrate that even in a reduced slice preparation, which lacks a SP, taurine increases the frequency of PSCs. Although different subpopulations of inhibitory interneurons can be identified in the mature neocortex based on molecular, morphological and electrophysiological parameters (Markram et al., 2004; Ascoli et al., 2008), the late development of these markers (Doischer et al., 2008; Okaty et al., 2009) does not allow a reliably identification of the prospective subtype of the recorded interneurons during early postnatal development. The intriguing question, whether specific GABAergic interneurons transiently integrate into immature excitatory circuits thus remains elusive. Interestingly, GABAergic interneurons receive reliably excitatory GABAergic inputs (Rheims et al., 2008), while at least in the somatosensory neocortex no reliably excitatory inputs from the thalamus were found in early postnatal stages (Daw et al., 2007), suggesting that GABAergic interneurons are integrated into transient, mainly GABAergic circuits that mediate excitation rather than the feed-forward inhibition typical for mature neocortical circuits. One intriguing observation of the present study is that a taurine-induced increase in PSC frequency was observed only in $46 \%$ of the investigated pyramidal neurons, indicating that only a portion of the pyramidal neurons was integrated into such functional GABAergic networks.

In the immature hippocampus early generated pioneer GABAergic interneurons synchronize network activity transients (Bonifazi et al., 2009; Picardo et al., 2011). Such spontaneous early activity transients occur in most developing neuronal networks and are supposed to promote the formation of functional networks (Spitzer, 2006; Hanganu-Opatz, 2010; Kilb et al., 2011). In the neocortex, however, spontaneous network activity or oscillatory events are mostly independent of $\mathrm{GABA}_{\mathrm{A}}$ receptors (Garaschuk et al., 2000; Dupont et al., 2006; Allene et al., 2008), although in ventral aspects of the neocortex a contribution of $\mathrm{GABA}_{\mathrm{A}}$ receptors to spontaneous activity has been reported in the first postnatal week (Conhaim et al., 2011). Therefore we propose that this GABAergic excitatory network does not directly contribute to large-scale activity transients, but controls the excitability of specific, probably more local excitatory networks. 
Finally, it has to be considered that the taurine concentration of $300 \mu \mathrm{M}$ used in the present study most likely exceeds the interstitial taurine levels that can be expected in the immature neocortex. However, in rat and human fetal brains taurine is the most abundant neurotransmitter (Das and Ray, 1997; BenitezDiaz et al., 2003). It has been suggested that taurine can be released from immature neurons after electrical stimulation or by hypoosmolar solution (Flint et al., 1998; Kilb et al., 2008) by nonsynaptic processes, e.g., by volume-sensitive organic osmolyte channels or reversal of taurine transport (Ando et al., 2012). Therefore we propose that such an activity-dependent nonsynaptic release of taurine can led to subtle changes in the interstitial taurine concentrations, which in turn slightly increase the excitability of immature networks and may thereby directly influence the maturation of neocortical neuronal circuits.

\section{AUTHOR CONTRIBUTIONS}

Werner Kilb designed the experiments, Bogdan A. Sava, Rongqing Chen and Haiyan Sun performed the experiments, Bogdan A. Sava and Werner Kilb analyzed the data, Heiko J. Luhmann and Werner Kilb wrote the manuscript.

\section{ACKNOWLEDGMENTS}

The authors thank Beate Krumm for excellent technical assistance. This work was supported by grants of China Scholarship Council (CSC) to Haiyan Sun and by grants of the Deutsche Forschungsgemeinschaft to Heiko J. Luhmann (DFG For 1341, BaCoFun) and Werner Kilb (KI 835/2). The GAD67GFP mice were kindly provided by Prof. Yuchio Yanagawa (Gunma University, Japan).

\section{REFERENCES}

Achilles, K., Okabe, A., Ikeda, M., Shimizu-Okabe, C., Yamada, J., Fukuda, A., et al. (2007). Kinetic properties of $\mathrm{Cl}$ uptake mediated by $\mathrm{Na}^{+}$-dependent $\mathrm{K}^{+}-2 \mathrm{Cl}$ cotransport in immature rat neocortical neurons. J. Neurosci. 27, 8616-8627. doi: 10.1523/jneurosci.5041-06.2007

Aguayo, L. G., van Zundert, B., Tapia, J. C., Carrasco, M. A., and Alvarez, F. J. (2004). Changes on the properties of glycine receptors during neuronal development. Brain Res. Brain Res Rev. 47, 33-45. doi: 10.1016/j.brainresrev.2004.06. 007

Albrecht, J., and Schousboe, A. (2005). Taurine interaction with neurotransmitter receptors in the CNS: an update. Neurochem. Res. 30, 1615-1621. doi: 10. 1007/s11064-005-8986-6

Allene, C., Cattani, A., Ackman, J. B., Bonifazi, P., Aniksztejn, L., Ben-Ari, Y., et al. (2008). Sequential generation of two distinct synapse-driven network patterns in developing neocortex. J. Neurosci. 28, 12851-12863. doi: 10.1523/jneurosci. 3733-08.2008

Ando, D., Kubo, Y., Akanuma, S., Yoneyama, D., Tachikawa, M., and Hosoya, K. (2012). Function and regulation of taurine transport in Muller cells under osmotic stress. Neurochem. Int. 60, 597-604. doi: 10.1016/j.neuint.2012.02.018

Ascoli, G. A., Alonso-Nanclares, L., Anderson, S. A., Barrionuevo, G., BenavidesPiccione, R., Burkhalter, A., et al. (2008). Petilla terminology: nomenclature of features of GABAergic interneurons of the cerebral cortex. Nat. Rev. Neurosci. 9, 557-568. doi: 10.1038/nrn2402

Behar, T. N., Schaffner, A. E., Scott, C. A., Greene, C. L., and Barker, J. L. (2000). GABA receptor antagonists modulate postmitotic cell migration in slice cultures of embryonic rat cortex. Cereb. Cortex 10, 899-909. doi: 10.1093/cercor/10.9.899

Behar, T. N., Smith, S. V., Kennedy, R. T., McKenzie, J. M., Maric, I., and Barker, J. L. (2001). GABA(B) receptors mediate motility signals for migrating embryonic cortical cells. Cereb. Cortex 11, 744-753. doi: 10.1093/cercor/11.8.744

Ben-Ari, Y. (2002). Excitatory actions of GABA during development: the nature of the nurture. Nat. Rev. Neurosci. 3, 728-739. doi: 10.1038/nrn920
Ben-Ari, Y. (2006). Basic developmental rules and their implications for epilepsy in the immature brain. Epileptic Disord. 8, 91-102.

Ben-Ari, Y. (2012). The yin and yen of GABA in brain development and operation in health and disease. Front. Cell. Neurosci. 6:45 doi: 10.3389/fncel.2012.00045

Ben-Ari, Y., Woodin, M. A., Sernagor, E., Cancedda, L., Vinay, L., Rivera, C., et al. (2012). Refuting the challenges of the developmental shift of polarity of GABA actions: GABA more exciting than ever! Front. Cell. Neurosci. 6:35 doi: 10. 3389/fncel.2012.00035

Ben-Ari, Y., Cherubini, E., Corradetti, R., and Gaiarsa, J.-L. (1989). Giant synaptic potentials in immature rat CA3 hippocampal neurones. J. Physiol. 416, 303-325.

Benitez-Diaz, P., Miranda-Contreras, L., Mendoza-Briceno, R. V., Pena-Contreras, Z., and Palacios-Pru, E. (2003). Prenatal and postnatal contents of amino acid neurotransmitters in mouse parietal cortex. Dev. Neurosci. 25, 366-374. doi: 10. 1159/000073514

Bonifazi, P., Goldin, M., Picardo, M. A., Jorquera, I., Cattani, A., Bianconi, G., et al. (2009). GABAergic hub neurons orchestrate synchrony in developing hippocampal networks. Science 326, 1419-1424. doi: 10.1126/science.117 5509

Bormann, J., Hamill, O. P., and Sakmann, B. (1987). Mechanism of anion permeation through channels gated by glycine and gamma-aminobutyric acid in mouse cultured spinal neurones. J. Physiol. 385, 243-286.

Carlson, V. C. C., and Yeh, H. H. (2011). GABA(A) receptor subunit profiles of tangentially migrating neurons derived from the medial ganglionic eminence. Cereb. Cortex 21, 1792-1802. doi: 10.1093/cercor/bhq247

Conhaim, J., Easton, C. R., Becker, M. I., Barahimi, M., Cedarbaum, E. R., Moore, J. G., et al. (2011). Developmental changes in propagation patterns and transmitter dependence of waves of spontaneous activity in the mouse cerebral cortex. J. Physiol. 589, 2529-2541. doi: 10.1113/jphysiol.2010.202382

Cosgrove, K. E., and Maccaferri, G. (2012). mGlul alpha-dependent recruitment of excitatory GABAergic input to neocortical Cajal-Retzius cells. Neuropharmacol. 63, 486-493. doi: 10.1016/j.neuropharm.2012.04.025

Cuzon, V. C., Yeh, P. W., Cheng, Q., and Yeh, H. H. (2006). Ambient GABA promotes cortical entry of tangentially migrating cells derived from the medial ganglionic eminence. Cereb. Cortex 16, 1377-1388. doi: 10.1093/cercor/bhj084

Dammerman, R. S., Flint, A. C., Noctor, S., and Kriegstein, A. R. (2000). An excitatory GABAergic plexus in developing neocortical layer 1. J. Neurophysiol. $84,428-434$.

Das, S. K., and Ray, P. K. (1997). Ontogeny of neurotransmitter amino acids in human fetal brains. Biochem. Mol. Biol. Int. 42, 193-202. doi: 10. 1080/15216549700202581

Daw, M. I., Ashby, M. C., and Isaac, J. T. (2007). Coordinated developmental recruitment of latent fast spiking interneurons in layer IV barrel cortex. Nat. Neurosci. 10, 453-461. doi: 10.1038/nn1866

Dodt, H.-U, and Zieglgänsberger, W. (1990). Visualizing unstained neurons in living brain slices by infrared DIC-videomicroscopy. Brain Res. 537, 333-336. doi: 10.1016/0006-8993(90)90380-t

Doischer, D., Hosp, J. A., Yanagawa, Y., Obata, K., Jonas, P., Vida, I., et al. (2008). Postnatal differentiation of basket cells from slow to fast signaling devices. $J$. Neurosci. 28, 12956-12968. doi: 10.1523/jneurosci.2890-08.2008

Dupont, E., Hanganu, I. L., Kilb, W., Hirsch, S., and Luhmann, H. J. (2006). Rapid developmental switch in the mechanisms driving early cortical columnar networks. Nature 439, 79-83. doi: 10.1038/nature04264

Flint, A. C., Liu, X. L., and Kriegstein, A. R. (1998). Nonsynaptic glycine receptor activation during early neocortical development. Neuron 20, 43-53. doi: 10. 1016/s0896-6273(00)80433-x

Fritschy, J. M., Paysan, J., Enna, A., and Mohler, H. (1994). Switch in the expression of rat $\mathrm{GABA}_{\mathrm{A}}$-receptor subtypes during postnatal development: an immunohistochemical study. J. Neurosci. 14, 5302-5324.

Garaschuk, O., Linn, J., Eilers, J., and Konnerth, A. (2000). Large-scale oscillatory calcium waves in the immature cortex. Nat. Neurosci. 3, 452-459. doi: 10. $1038 / 74823$

Gozlan, H., and Ben-Ari, Y. (2003). Interneurons are the source and the targets of the first synapses formed in the rat developing hippocampal circuit. Cereb. Cortex 13, 684-692. doi: 10.1093/cercor/13.6.684

Hanganu, I. L., Kilb, W., and Luhmann, H. J. (2002). Functional synaptic projections onto subplate neurons in neonatal rat somatosensory cortex. J. Neurosci. 22, 7165-7176.

Hanganu-Opatz, I. L. (2010). Between molecules and experience: role of early patterns of coordinated activity for the development of cortical maps and 
sensory abilities. Brain Res. Rev. 64, 160-176. doi: 10.1016/j.brainresrev.2010. 03.005

Haydar, T. F., Wang, F., Schwartz, M. L., and Rakic, P. (2000). Differential modulation of proliferation in the neocortical ventricular and subventricular zones. $J$. Neurosci. 20, 5764-5774.

Heck, N., Kilb, W., Reiprich, P., Kubota, H., Furukawa, T., Fukuda, A., et al. (2007). $\mathrm{GABA}_{\mathrm{A}}$ receptors regulate neocortical neuronal migration in vitro and in vivo. Cereb. Cortex 17, 138-148. doi: 10.1093/cercor/bhj135

Hessler, N. A., Shirke, A. M., and Malinow, R. (1993). The probability of transmitter release at a mammalian central synapse. Nature 366, 569-572. doi: 10. $1038 / 366569 \mathrm{a} 0$

Inoue, K., Furukawa, T., Kumada, T., Yamada, J., Wang, T. Y., Inoue, R., et al. (2012). Taurine inhibits $\mathrm{K}^{+}-\mathrm{Cl}^{-}$cotransporter $\mathrm{KCC} 2$ to regulate embryonic $\mathrm{Cl}^{-}$homeostasis via With-no-lysine (WNK) protein kinase signaling pathway. J. Biol. Chem. 287, 20839-20850. doi: 10.1074/jbc.m111.319418

Ito, S., and Cherubini, E. (1991). Strychnine-sensitive glycine responses of neonatal rat hippocampal neurones. J. Physiol. 440, 67-83.

Jedlicka, P., Deller, T., Gutkin, B. S., and Backus, K. H. (2011). Activity-dependent intracellular chloride accumulation and diffusion controls GABA(A) receptormediated synaptic transmission. Hippocampus 21, 885-898. doi: 10.1002/hipo. 20804

Ji, F. Y., Kanbara, N., and Obata, K. (1999). GABA and histogenesis in fetal and neonatal mouse brain lacking both the isoforms of glutamic acid decarboxylase. Neurosci. Res. 33, 187-194. doi: 10.1016/s0168-0102(99)00011-5

Kanold, P. O., and Luhmann, H. J. (2010). The subplate and early cortical circuits. Annu. Rev. Neurosci. 33, 23-48. doi: 10.1146/annurev-neuro-060909-153244

Kilb, W., and Luhmann, H. J. (2001). Spontaneous GABAergic postsynaptic currents in Cajal-Retzius cells in neonatal rat cerebral cortex. Eur. J. Neurosci. 13, 1387-1390. doi: 10.1046/j.0953-816x.2001.01514.x

Kilb, W., Hanganu, I. L., Okabe, A., Sava, B. A., Shimizu-Okabe, C., Fukuda, A., et al. (2008). Glycine receptors mediate excitation of subplate neurons in neonatal rat cerebral cortex. J. Neurophysiol. 100, 698-707. doi: 10.1152/jn. 00657.2007

Kilb, W., Ikeda, M., Uchida, K., Okabe, A., Fukuda, A., and Luhmann, H. J. (2002). Depolarizing glycine responses in Cajal-Retzius cells of neonatal rat cerebral cortex. Neuroscience 112, 299-307. doi: 10.1016/s0306-4522(02)00071-4

Kilb, W., Kirischuk, S., and Luhmann, H. J. (2011). Electrical activity patterns and the functional maturation of the neocortex. Eur. J. Neurosci. 34, 1677-1686. doi: 10.1111/j.1460-9568.2011.07878.x

Kilb, W., Kirischuk, S., and Luhmann, H. J. (2013). Role of tonic GABAergic currents during pre- and early postnatal rodent development. Front. Neural Circ. 7:139. doi: 10.3389/fncir.2013.00139

Kirmse, K., and Kirischuk, S. (2006). Ambient GABA constrains the strength of GABAergic synapses at Cajal-Retzius cells in the developing visual cortex. $J$. Neurosci. 26, 4216-4227. doi: 10.1523/jneurosci.0589-06.2006

Kolbaev, S. N., Achilles, K., Luhmann, H. J., and Kilb, W. (2011a). Effect of depolarizing GABA(A)-mediated membrane responses on excitability of CajalRetzius cells in the immature rat neocortex. J. Neurophysiol. 106, 2034-2044. doi: 10.1152/jn.00699.2010

Kolbaev, S. N., Luhmann, H. J., and Kilb, W. (2011b). Activity-dependent scaling of GABA-ergic excitation by dynamic $\mathrm{Cl}(-)$ changes in Cajal-Retzius cells. Pflugers Arch. 461, 557-565. doi: 10.1007/s00424-011-0935-4

Kolbaev, S. N., Sharopov, S., Dierkes, P. W., Luhmann, H. J., and Kilb, W. (2012). Phasic GABAA-receptor activation is required to suppress epileptiform activity in the CA3 region of the immature rat hippocampus. Epilepsia 53, 888-896. doi: 10.1111/j.1528-1167.2012.03442.x

Kriegstein, A. R., Suppes, T., and Prince, D. A. (1987). Cellular and synaptic physiology and epileptogenesis of developing rat neocortical neurons in vitro. Brain Res. 431, 161-171. doi: 10.1016/0165-3806(87)90206-9

Laurie, D. J., Wisden, W., and Seeburg, P. H. (1992). The distribution of thirteen $\mathrm{GABA}_{\mathrm{A}}$ receptor subunit mRNAs in the rat brain. III. Embryonic and postnatal development. J. Neurosci. 12, 4151-4172.

LoTurco, J. J., Owens, D. F., Heath, M. J., Davis, M. B., and Kriegstein, A. R. (1995). GABA and glutamate depolarize cortical progenitor cells and inhibit DNA synthesis. Neuron 15, 1287-1298. doi: 10.1016/0896-6273(95)90 008-x

Luhmann, H. J., Kilb, W., and Hanganu-Opatz, I. L. (2009). Subplate cells: amplifiers of neuronal activity in the developing cerebral cortex. Front. Neuroanat. 3:19. doi: 10.3389/neuro.05.019.2009
Luhmann, H. J., Reiprich, R. A., Hanganu, I., and Kilb, W. (2000). Cellular physiology of the neonatal rat cerebral cortex: intrinsic membrane properties, sodium and calcium currents. J. Neurosci. Res. 62, 574-584. doi: 10.1002/10974547(20001115)62:4<574::aid-jnr12>3.0.co;2-0

Maar, T., Moran, J., Schousboe, A., and Pasantes-Morales, H. (1995). Taurine deficiency in dissociated mouse cerebellar cultures affects neuronal migration. Int. J. Dev. Neurosci. 13, 491-502. doi: 10.1016/0736-5748(95)00068-r

Markram, H., Toledo-Rodriguez, M., Wang, Y., Gupta, A., Silberberg, G., and Wu, C. (2004). Interneurons of the neocortical inhibitory system. Nat. Rev. Neurosci. 5, 793-807. doi: 10.1038/nrn1519

Oja, S. S., and Saransaari, P. (2000). Modulation of taurine release by glutamate receptors and nitric oxide. Prog. Neurobiol. 62, 407-425. doi: 10.1016/s03010082(00)00005-8

Okabe, A., Kilb, W., Shimizu-Okabe, C., Hanganu, I. L., Fukuda, A., and Luhmann, H. J. (2004). Homogenous glycine receptor expression in cortical plate neurons and Cajal-Retzius cells of neonatal rat cerebral cortex. Neuroscience 123, 715724. doi: 10.1016/j.neuroscience.2003.10.014

Okaty, B. W., Miller, M. N., Sugino, K., Hempel, C. M., and Nelson, S. B. (2009). Transcriptional and electrophysiological maturation of neocortical fast-spiking GABAergic interneurons. J. Neurosci. 29, 7040-7052. doi: 10.1523/jneurosci. 0105-09.2009

Owens, D. F., Boyce, L. H., Davis, M. B., and Kriegstein, A. R. (1996). Excitatory GABA responses in embryonic and neonatal cortical slices demonstrated by gramicidin perforated-patch recordings and calcium imaging. J. Neurosci. 16, 6414-6423.

Owens, D. F., Liu, X. L., and Kriegstein, A. R. (1999). Changing properties of $\mathrm{GABA}_{\mathrm{A}}$ receptor-mediated signaling during early neocortical development. $J$. Neurophysiol. 82, 570-583.

Palackal, T., Moretz, R., Wisniewski, H., and Sturman, J. (1986). Abnormal visual cortex development in the kitten associated with maternal dietary taurine deprivation. J. Neurosci. Res. 15, 223-239. doi: 10.1002/jnr.490150212

Paxinos, G., and Franklin, K. B. J. (2001). The Mouse Brain in Stereotaxic Coordinates. San Diego: Academic Press.

Picardo, M. A., Guigue, P., Bonifazi, P., Batista-Brito, R., Allene, C., Ribas, A., et al. (2011). Pioneer GABA cells comprise a subpopulation of hub neurons in the developing hippocampus. Neuron 71, 695-709. doi: 10.1016/j.neuron.2011.06. 018

Picken Bahrey, H. L., and Moody, W. J. (2003). Early development of voltage-gated ion currents and firing properties in neurons of the mouse cerebral cortex. $J$. Neurophysiol. 89, 1761-1773. doi: 10.1152/jn.00972.2002

Radnikow, G., Feldmeyer, D., and Lubke, J. (2002). Axonal projection, input and output synapses and synaptic physiology of Cajal-Retzius cells in the developing rat neocortex. J. Neurosci. 22, 6908-6919.

Rheims, S., Minlebaev, M., Ivanov, A., Represa, A., Khazipov, R., Holmes, G. L., et al. (2008). Excitatory GABA in rodent developing neocortex in vitro. J. Neurophysiol. 100, 609-619. doi: 10.1152/jn.90402.2008

Rivera, C., Voipio, J., Payne, J.A., Ruusuvuori, E., Lahtinen, H., Lamsa, K., et al. (1999). The $\mathrm{K}^{+} / \mathrm{Cl}^{-}$co-transporter KCC2 renders GABA hyperpolarizing during neuronal maturation. Nature 397, 251-255. doi: 10.1038/16697

Saransaari, P., and Oja, S. S. (1998). Mechanisms of ischemia-induced taurine release in mouse hippocampal slices. Brain Res. 807, 118-124. doi: 10. 1016/s0006-8993(98)00793-8

Sernagor, E., Chabrol, F., Bony, G., and Cancedda, L. (2010). GABAergic control of neurite outgrowth and remodeling during development and adult neurogenesis: general rules and differences in diverse systems. Front. Cell. Neurosci. 4:11. doi: 10.3389/fncel.2010.00011

Sipila, S. T., Huttu, K., Soltesz, I., Voipio, J., and Kaila, K. (2005). Depolarizing GABA acts on intrinsically bursting pyramidal neurons to drive giant depolarizing potentials in the immature hippocampus. J. Neurosci. 25, 5280-5289. doi: 10. 1523/jneurosci.0378-05.2005

Spitzer, N. C. (2006). Electrical activity in early neuronal development. Nature 444, 707-712. doi: 10.1038/nature 05300

Stell, B. M., and Mody, I. (2002). Receptors with different affinities mediate phasic and tonic GABA(A) conductances in hippocampal neurons. J. Neurosci. 22, RC223 (1-5).

Sturman, J. A., Lu, P., Xu, Y. X., and Imaki, H. (1994). Feline maternal taurine deficiency: effects on visual cortex of the offspring. A morphometric and immunohistochemical study. Adv. Exp. Med. Biol. 359, 369-384. doi: 10. 1007/978-1-4899-1471-2_38 
Tamamaki, N., Yanagawa, Y., Tomioka, R., Miyazaki, J., Obata, K., and Kaneko, T. (2003). Green fluorescent protein expression and colocalization with calretinin, parvalbumin and somatostatin in the GAD67-GFP knock-in mouse. J. Comp. Neurol. 467, 60-79. doi: 10.1002/cne.10905

Van Eden, C. G., Parmar, R., Lichtensteiger, W.,and Schlumpf, M. (1995). Laminar distribution of $\mathrm{GABA}_{\mathrm{A}}$ receptor $\alpha_{1}, \beta_{2}$ and $\gamma_{2}$ subunit mRNAs in the granular and agranular frontal cortex of the rat during pre- and postnatal development. Cereb. Cortex 5, 234-246. doi: 10.1093/cercor/5.3.234

Wang, D. D., and Kriegstein, A. R. (2008). GABA regulates excitatory synapse formation in the neocortex via NMDA receptor activation. J. Neurosci. 28, 55475558. doi: 10.1523/jneurosci.5599-07.2008

Wang, D. D., and Kriegstein, A. R. (2009). Defining the role of GABA in cortical development. J. Physiol. 587, 1873-1879. doi: 10.1113/jphysiol.2008.167635

Wojcik, S. M., Katsurabayashi, S., Guillemin, I., Friauf, E., Rosenmund, C., Brose, N., et al. (2006). A shared vesicular carrier allows synaptic corelease of GABA and glycine. Neuron 50, 575-587. doi: 10.1016/j.neuron.2006.04.016
Conflict of Interest Statement: The authors declare that the research was conducted in the absence of any commercial or financial relationships that could be construed as a potential conflict of interest.

Received: 24 September 2013; accepted: 17 January 2014; published online: 04 February 2014.

Citation: Sava BA, Chen R, Sun H, Luhmann HJ and Kilb W (2014) Taurine activates GABAergic networks in the neocortex of immature mice. Front. Cell. Neurosci. 8:26. doi: 10.3389/fncel.2014.00026

This article was submitted to the journal Frontiers in Cellular Neuroscience. Copyright (C) 2014 Sava, Chen, Sun, Luhmann and Kilb. This is an open-access article distributed under the terms of the Creative Commons Attribution License (CC BY). The use, distribution or reproduction in other forums is permitted, provided the original author(s) or licensor are credited and that the original publication in this journal is cited, in accordance with accepted academic practice. No use, distribution or reproduction is permitted which does not comply with these terms. 